\title{
INTEGRATED QUALITY MANAGEMENT SYSTEM AT FOOD ENTERPRISES IN RUSSIA
}

\author{
Regina Gurina, Anton Poddubsky, Viktoriya Sinenko \\ Peoples' Friendship University of Russia, Russia \\ gurina_rr@pfur.ru, a.poddubskiy@mail.ru,sinenko_va@pfur.ru
}

\begin{abstract}
The article is devoted to the study of issues related to the development and implementation of a quality management system at food enterprises. The process of implementing a quality management system at food industry enterprises in Russia is a whole complex of activities aimed at a full, deep and holistic analysis of the actual state, real opportunities and prospects for the company's development. The quality management system in many countries of the world allows to optimize the activities of the enterprise, tune in to prevent failures and inconsistencies and produce products that best meet the expectations and preferences of consumers. The introduction of QMS at enterprises is associated with a change in the modern economic model, which requires more demands of the products. In order to ensure that Russian products are competitive in the world market, it is necessary to fulfill the requirements of international standards in the field of food quality assurance. In the paper, the main harmonized (reduced to the unity with the world requirements) normative acts in the field of food quality assurance, applied in Russia, are analyzed. It was revealed that introduction of QMS will allow to identify, assess and manage risks at food enterprises on time, and also to increase their competitiveness. The author substantiates the necessity of introducing the system of quality and safety at food enterprises. It was revealed that the principles of the quality management system, oriented to the consumer, in accordance with GOST R ISO 10001-2009, will ensure the efficiency and progress of food enterprises.
\end{abstract}

Keywords: quality management system, QMS principles, nutrition, product safety, product quality, quality management.

\section{Introduction}

Currently, most organizations believe that the main reason for forcing the organization to achieve excellent quality is the desire to satisfy ever-growing demands of consumers. It is accepted that if quality is a benefit for consumers, companies and society as a whole, its absence is their general dissatisfaction.

The industry of public catering is the organization of production and realization services and organization of population's leisure. Therefore, quality management in the industry of public catering is the implementation of mutually dependent and interrelated operations, starting from the acceptance of raw materials, its processing and ending with the storage of finished products. To ensure the competitiveness of public catering enterprises in the conditions of the modern market, it is necessary to create such conditions that it can provide the population with quality services and produce highquality food products, and for this it is necessary to create the effective quality management system.

Currently processes of quality management in food enterprises come down to development of production control programs, control of developed dishes and culinary products, as well as filling of the journal and sanitary and technological documentation. Food enterprises should work in such a way that indicators "quality" and "safety" become for them the system process that covers all parameters of manufacturing products, enhances its competitiveness, and attracts potential consumers.

To solve these provisions at food enterprises in Russia, the most effective means is the implementation of QMS requirements based on the use of integrated quality management system at food enterprises. The management system (QMS) is a system that is created at enterprises for the purpose of continuous policies and objectives formation in the field of quality, and also to achieve these goals. This system assumes a reduction in the probability of manufacturing defective products.

ISO 9000 series standards set the methodology for functioning of the quality system, which should ensure high quality of products and services and ensure high degree of customer satisfaction [1].

The national standard GOST R ISO 9000-2015 [2], in relation to the process, gives the following definition: quality management of the process is the coordinated activity to guide and manage the process with regard to its quality, which includes process quality planning, process quality assurance, process quality management and improvement of the process quality [3].

The process quality management cycle corresponds to the PDCA Deming cycle by the number of stages and their sequence: 
- plan: this is the development of the system objectives, as well as its processes and the identification of resources that are necessary to obtain results according to the needs of consumers and the organization's policy, identify risks and opportunities for the organization;

- $d o$ : this is the fulfillment of the scenario;

- check: this is the monitoring of processes, products and services according to policy, goals, requirements and planned actions;

- act: this is the adoption of measures to improve the results of activities, if necessary [3].

The quality of the process is necessarily planned with the quality of its result (i.e., output), because the quality of the process must lead to ensuring the appropriate quality of products or services or works output. At food enterprises in Russia, input data for the implementation of process quality planning are:

- strategy and objectives of the enterprise with regard to the quality of its activities;

- definition of needs and expectations of consumers and other interested parties;

- information on existing legislative and other mandatory requirements;

- data on the characteristics of products (works, services);

- data on process indicators;

- lessons learned from previous experience;

- available opportunities for improving processes;

- estimation of corresponding risks, and also possibilities of their decrease, etc.

The main output data when planning the quality of processes, as well as their results, should be the following:

- transformed needs and expectations of the processes quality and their results in requirements;

- requirements from consumers, which are expressed in quantitative indicators of processes properties and their outputs;

- planned values of process indicators, as well as their outputs;

- qualimetric assessment of levels of planned qualities of processes, as well as their outputs;

- methods and means (technologies) to achieve planned indicators of the properties and qualities of processes, as well as their outputs.

\section{Results and discussion}

The main task of the quality management system (QMS) at Russian enterprises is not only to promote the production of high-quality products or to perform high-quality services, but also to create confidence that the product or service will have the same characteristics in the future. The development of such confidence is not only the sufficient provision of production processes, the performance of certain works or the provision of services, but also through systematic confirmation that the requirements for the quality of processes in the enterprise are met and that the results of these processes also comply with the requirements for their purpose: use and application.

In order to increase the effectiveness of management and improve the activities of food enterprises in Russia working on the principles of GOST R ISO 9000-2015, the requirements of additional standards of recommendatory nature come into force.

National Standard GOST R ISO 9004-2010 "Management for the achievement of sustainable success of the organization. The Quality Management Approach "provides recommendations for achieving sustainable enterprise success in complex and ever-changing environment through the use of an approach based on the quality management system [4].

The quality of services is regulated by the international standard ISO 9004-2-91 "Administrative quality management and quality system elements". In Russia, the national standard GOST R 521132014 "Services to the public. Nomenclature of quality indicators".

GOST 31985-2013 "Public catering services. Terms and Definitions "defines the catering service as a result of public catering enterprise activity (a legal entity or an individual entrepreneur) to satisfy consumers in catering products, including creating the necessary conditions for realization and consumption of these products, leisure and other additional services [5]. 
When organizing the provision of catering services, enterprises must guarantee consumers high quality of products they provide; cleanliness, hygiene, aesthetics of the public catering establishment; clear service (staff must be competent and polite); personal safety and security of their property (including fire, technical, sanitary and environmental) [6].

The process approach in public catering provides for continuous monitoring of customer satisfaction and determination of their preferences, which are taken into account in national standards: GOST R ISO 10001-2009 and GOST R ISO 10003-2009. The introduction of these standards into the work of public catering establishments increases the confidence of consumers and improves their image. They are directed to:

- development and production of catering products, taking into account the views of the target segments;

- implementation of interaction with consumers of catering products;

- implementation of all processes improvement that are aimed at meeting the needs of customers;

- implementation of comparative analysis of consumer characteristics of substitute goods and (or) competitor products.

GOST R ISO 10001-2009 defines customer satisfaction as perception of fulfillment degree of their requirements. To develop and implement QMS for public catering enterprises, it is necessary to follow the principles of QMS in terms of customer orientation (Table 1).

Table 1

Guidelines for the quality management system, customer-oriented, in accordance with GOST R ISO 10001-2009

\begin{tabular}{|c|l|}
\hline Principles & \multicolumn{1}{|c|}{ Description of requirements } \\
\hline 1 & \multicolumn{1}{|c|}{2} \\
\hline $\begin{array}{c}\text { Compliance } \\
\text { with obligations }\end{array}$ & Food enterprise takes obligations to fulfill its promise \\
\hline Possibility & Provision of the necessary resources to satisfy consumers \\
\hline Visibility & $\begin{array}{l}\text { All interested parties should have information about the rules of conduct to } \\
\text { satisfy consumers }\end{array}$ \\
\hline Availability & $\begin{array}{l}\text { Ensuring the availability of all information that concerns rules. Such } \\
\text { information should not be allowed to be interpreted in two ways }\end{array}$ \\
\hline Responsiveness & $\begin{array}{l}\text { The ability to identify and listen to the views of stakeholder, including } \\
\text { determination of financial and human resources that are associated with } \\
\text { obtaining input from stakeholders }\end{array}$ \\
\hline Accuracy & Rules and information should be clear and precise, should not be misleading \\
\hline $\begin{array}{c}\text { Reporting } \\
\text { improvements }\end{array}$ & $\begin{array}{l}\text { Obligations to implement and maintain accountability for actions in relation to } \\
\text { the rules on consumer satisfaction }\end{array}$ \\
\hline
\end{tabular}

\section{Conclusions}

Proceeding from the foregoing, we can say that the implementation of the standard GOST R ISO 9000-2015, based on internationally recognized concepts and requirements at the food enterprises, will increase the effectiveness and efficiency of product quality management. Fulfillment of all GOST R ISO 9000-2015 requirements, as well as additional standards aimed at the consumer, is the most effective way to improve the quality of food products, with minimal time and money. Despite the fact that all these principles of QMS, which are aimed at satisfying consumers, are recommendatory for catering enterprises, every enterprise in Russia must implement the quality management system on the mandatory basis in order to ensure its competitiveness not only on the national, but also on international level.

Settlement of disputed issues in accordance with the quality management system should be carried out in accordance with the principles of GOST R ISO 10003-2009 "Quality management. 
Satisfaction of consumers. Recommendations for the settlement of disputes outside the organization"the principles of legality, impartiality, competence, timeliness, transparency.

In order for the quality system function effectively and be supported by the company's management, it must be implemented at the level of the company's structural management and included in the overall management processes. In order to develop, implement and maintain and continuously improve the quality management system, the organization forms the appropriate organizational structure - the head of the organization, the representative of the quality manual, the coordination council under the head of the organization, as well as the responsible representatives of organizational units of the organization. For successful management of the organization and its functioning, it is necessary to implement management systematically, openly and transparently.

If all of the above requirements are fulfilled, the quality management system at Russian food enterprises will provide for the implementation of services based on the principles of the quality management system aimed at meeting the population's needs for quality nutrition and leisure.

\section{Acknowledgements}

The publication was prepared with the support of the "RUDN University program 5-100".

\section{References}

[1] Gembris C. Quality Management / C. Gembris, J. Herrmann; Trans. with german by Terekhin M. N. - Moscow: SmartBuk, 2013, 128 p.

[2] ISO 9001:2015 Quality management systems - requirements Guidance Document. [online][19.03.1028] Available at: https://www.dnvgl.se/Images/ISO-9001-2015-GUIDANCE DOCUMENT_tcm37-56525.PDF

[3] ГОСТ Р ИСО 9001-2015 «Системы Менеджмента Качества: Требования». (GOST R ISO 9001-2015 “Quality Management System: Requirements”) - Moscow, Standartinform.2015, 25 p. (In Russian)

[4] Барышникова Н. И., Зайцева Т. Н., Мироманова Ю. В., Бакланова В. В. Управление качеством на предприятиях общественного питания (Quality management at public catering enterprises) // Молодой ученый, 2017, №1., pp. 145-149. (In Russian)

[5] Долматова И. А., Курочкина Т. И., Быстрова А. А. Фудкост - инструмент контроля затрат предприятия питания /Современные технологии продуктов питания (Fodkost - a tool for controlling the costs of food enterprises / Modern technology of food products): Междунар. науч.-прак. конф. - Курск: Юго-Зап. Гос. ун-т, 2014, pp. 72-74. (In Russian)

[6] Управление качеством на предприятиях пищевой, перерабатывающей промышленности, торговли и общественного питания: Учебник (Quality management in food, processing industry, trade and public catering enterprises: Textbook) / Под общ. ред. проф. В. М. Позняковского- 3-е изд. - М.: ИНФРА-М, 2014, 336 p. (In Russian) 